\title{
Correction to: Effect of antinuclear antibodies on pharmacokinetics of anti-TNF therapy in patients with inflammatory bowel disease
}

Eirini Theodoraki ${ }^{1} \cdot$ Eleni Orfanoudaki ${ }^{1} \cdot$ Kalliopi Foteinogiannopoulou $^{1} \cdot$ Nikolaos-Panagiotis Andreou $^{2}$. Maria Gazouli $^{2} \cdot$ loannis E. Koutroubakis ${ }^{1}$ (D)

Published online: 29 January 2022

๑) Springer-Verlag GmbH Germany, part of Springer Nature 2022

Correction to: International Journal of Colorectal Disease https://doi.org/10.1007/s00384-021-04091-6

In the original version of this article, Fig. 3 contained images that were not in correct order. The figure should have appeared as shown below.

The original article can be found online at https://doi.org/10.1007/ s00384-021-04091-6.

Eirini Theodoraki

eirinith25@yahoo.gr

$\bowtie$ Ioannis E. Koutroubakis

koutroui@uoc.gr

1 Department of Gastroenterology, Medical School, University Hospital of Heraklion, University of Crete, P.O. BOX 1352,

71110 Heraklion, Crete, Greece

2 Department of Basic Medical Sciences, Laboratory of Biology, School of Medicine, National and Kapodistrian University of Athens, Athens, Greece 

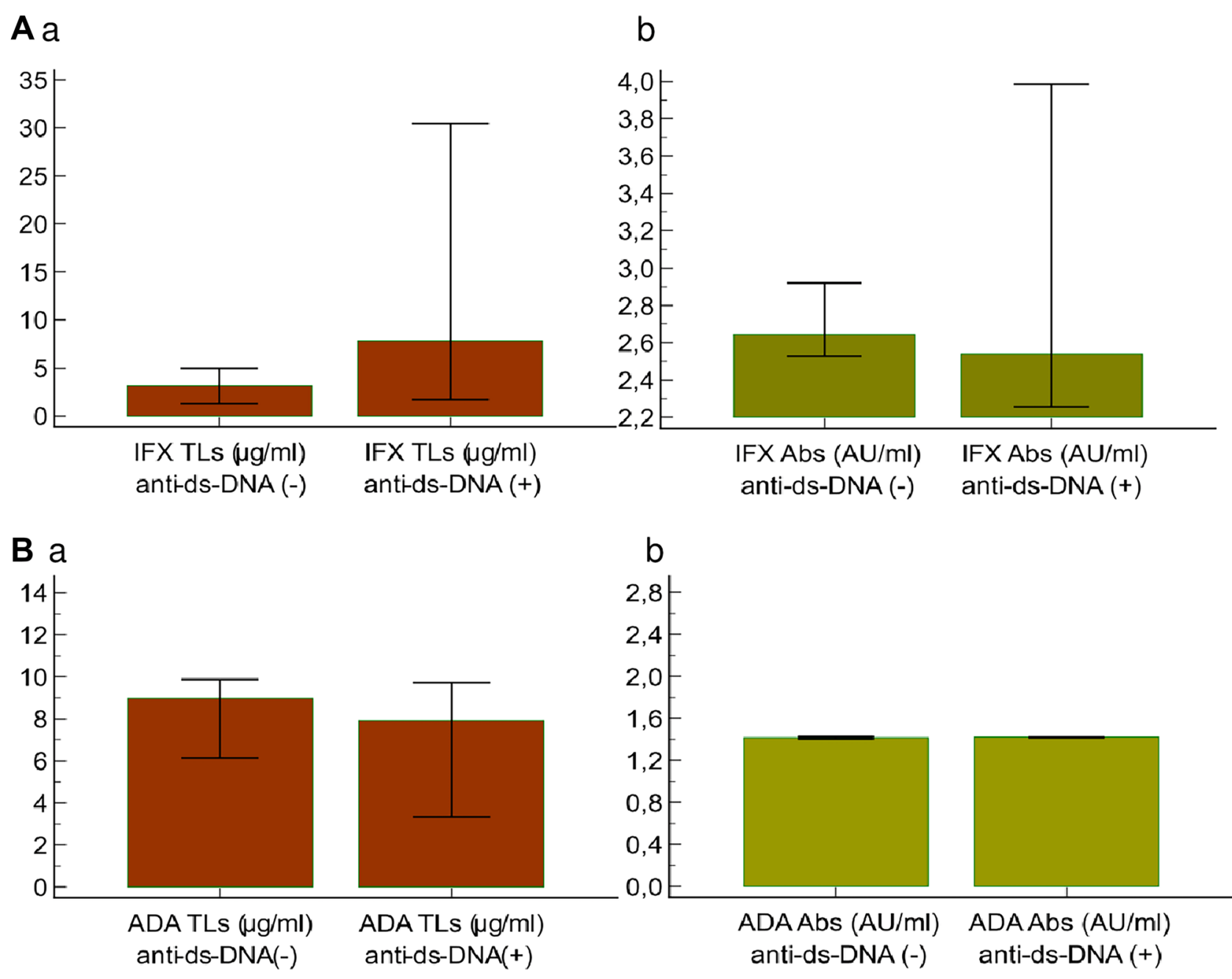

Fig. 3 A Comparison of IFX $\mathbf{a}$ TLs and $\mathbf{b}$ antibodies of anti-ds-DNA (-) $(\mathrm{N}=42)$ and anti-ds-DNA $(+)(\mathrm{N}=8)$ patients $(\mathrm{P}=0.24$ and $\mathrm{P}=0.98)$. B Comparison of ADA $\mathbf{a}$ TLs and $\mathbf{b}$ antibodies of anti-ds-DNA $(-)(\mathrm{N}=32)$ and anti-ds-DNA (+) $(\mathrm{N}=20)$ patients $(\mathrm{P}=0.82$ and $\mathrm{P}=0.79)$

The original article has been corrected.

Publisher's Note Springer Nature remains neutral with regard to jurisdictional claims in published maps and institutional affiliations. 